\title{
COVID-19 Pandemic Management in a Pediatric Clinic
}

\author{
Bir Pediatri Kliniğinde COVID-19 Pandemi Yönetimi
}

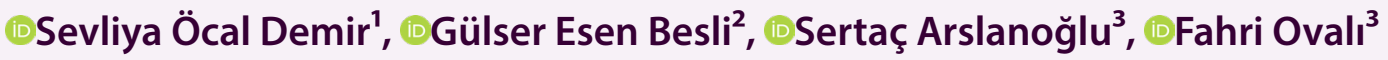 \\ 'Istanbul Medeniyet University Goztepe Prof. Dr. Suleyman Yalcın City Hospital, Pediatric Department, Pediatric Infectious Disease, \\ Istanbul, Turkey \\ ${ }^{2}$ Istanbul Medeniyet University Goztepe Prof. Dr. Suleyman Yalcın City Hospital, Pediatric Department, Pediatric Emergency, Istanbul, \\ Turkey \\ ${ }^{3}$ Istanbul Medeniyet University Goztepe Prof. Dr. Suleyman Yalcın City Hospital, Pediatric Department, Neonatology, Istanbul, Turkey
}

\begin{abstract}
Coronavirus Disease 2019 (COVID-19) outbreak was announced as a pandemic by World Health Organization (WHO) on March 12,2020 . This caution alerted all countries to determine their strategies to detect infection and control its spread. While infection control measures were taken in community, their crucial role in health care centers to safe both patients' and health care workers (HCW)'s life was noticed. During this pandemic each hospital begin to implement infection control measures according to their need and capacity. Here we presented infection control measures that were conducted in a pediatric clinic to control COVID-19 outbreak; including education of $\mathrm{HCW}$, preparedness of departments, rearrangement of staff employment, surveillance, and daily meeting with hospital administration to meet the changing needs. Timely identification and meeting of needs is crucial for the control of the outbreak during dynamic process of COVID-19 pandemic.
\end{abstract}

Keywords: COVID-19, pandemic, pediatric, control, measures

\section{Öz}

Dünya Sağlık Örgütü (DSÖ) 12 Mart 2020'de Koronavirüs Hastalığı 2019 (COVID-19) salgınını pandemi ilan etti. Bu durum tüm ülkeleri enfeksiyonu tespit etme ve yayılmasını kontrol altına alma stratejilerini belirlemeleri konusunda harekete geçirdi. Toplum için enfeksiyon kontrol önlemleri alınırken, sağlık merkezlerinde hem hastaların hem de sağlık hizmeti çalışanlarının (SHÇ) hayatını güvence altına almada bu önlemlerin hayati rolü fark edildi, her hastane ihtiyaçları ve kapasitelerine göre enfeksiyon kontrol önlemleri uygulamaya başladı. Bu yazıda COVID-19 salgınını kontrol altına almak için bir pediatri kliniğinde yürütülen SHÇ'nin eğitimi, departmanların hazırlığı, personel istihdamının yeniden düzenlenmesi, gözetim ve değişen ihtiyaçları karşılamak için hastane idaresi ile günlük toplantılar ve kararlar alınması dahil enfeksiyon kontrol önlemleri anlatıldı. COVID-19 pandemisinin dinamik süreci sırasında salgının kontrolü için ihtiyaçların zamanında belirlenip ve karşılanmasının önemli olduğu görüldü.

Anahtar Kelimeler: COVID-19, pandemi, pediyatri, kontrol, önlemleri

\section{INTRODUCTION}

In December 2019, a novel coronavirus was identified as the cause of acute respiratory illness in Wuhan, China. Subsequently in February, World Health Organization (WHO) named the disease Coronavirus Disease 2019 (COVID-19) and the novel coronavirus as severe acute respiratory syndrome coronavirus 2 (SARS-CoV-2). Although mortality rate in SARS-CoV-2 infection is lower than that in SARS-CoV-1, the virus spreads more rapidly, effected more than 198 countries/territories, infected $17,106,007$ cases, and caused 668,910 death by July 31 , 2020 (1). The WHO Director-General declared that the outbreak of COVID-19 continues to constitute a public health emergency of international concern (PHEIC). It has serious challenges on health care system worldwide. Functioning of health care system is vital during an epidemic, because it provide diagnosis, medical care, treatment and protection of people. Effective infection control measures are required to keep hospitals safe and functional. Health care associated outbreaks in hospital not only cause fear among patients and healthcare workers (HCWs), but also cause significant morbidities and mortalities. Chang et al stated that higher mortality 
rate of COVID-19 in Wuhan in contrast to other areas of China was due to deterioration of the health-care system following the nosocomial transmission (2).

Avoiding nosocomial outbreaks in the Pediatric Clinic may be more challenging since the role of children in transmission of infection to the other people, including HCW, may be overlooked because of their vague symptoms and milder illness. Therefore, infection control measures should be well established and implemented in pediatric clinics. Here we present our experience and strategies carried out in the Pediatric Clinic of İstanbul Medeniyet University Göztepe Prof. Dr. Süleyman Yalçın City Hospital (IMU GSYCH) to manage and control COVID-19 pandemic.

\section{Infection control measures in Pediatric Clinic of IMU GSYCH}

Before outbreak began in our country, a scientific advisory committee was set up at Ministry of Health $(\mathrm{MoH})$ to aid to monitor COVID-19 cases and suggest infection control measures all over the country. At January 24, 2020, they issued the first version of COVID-19 guideline which included main measures similar to WHO recommendations. Simultaneously in our hospital the pandemic control team was formed, including chief physician, deputy chief physicians, physicians of infectious diseases, of emergency department, of anesthesia and reanimation, of pediatric clinic, financial affairs manager, and manager of assistant medical staff. This team met every morning to monitor the admitted cases, to evaluate effectiveness of infection control measures implemented by the hospital, to determine needs, discuss opinions and suggestions about updated guidelines and its applicability to our hospital. The following arrangements were made by the advices and decisions of this executive team.

\section{Educational activities}

To prepare to confront SARS-CoV-2 infection, health-care workers (HCWs)' education began at the end of January 2020, before first case of COVID-19 was seen in Turkey. MoH's COVID-19 guideline was used for practice and education (3). However, because of limited data about the pediatric COVID-19, its recommendations were mainly for adults, but they were adopted to pediatric patients. With usage of online learning programs, educational programs were carried out for all health-care workers. Briefing about COVID-19 guideline was conducted regularly, the frequently revised COVID-19 definitions and updated information was simplified with algorithms and HCWs were informed about them by regular meetings (Figure 1). During meetings the latest situation of COVID-19 in the world, in our country and hospital were reviewed. Brochures about COVID-19 case definition, nasopharyngeal swap test indications were hanged in areas where suspected COVID-19 patients were evaluated.
Infection control measures implemented by our hospital and appropriate usage of personal protection equipment (PPE) were explained and demonstrated by video. Illustrated brochures about usage of PPE were hanged at the doors of all isolation wards as well as intensive care units and interventional units. Pediatricians and residents were educated for rapid sequential intubation of suspected or confirmed COVID-19 patients with video-guided laryngoscopy (Figure 2). Infection Control Nurses visited all departments regularly to determine the needs, monitor the already taken measures and their compliance and delivered practical education to HCWs about infection control measures.

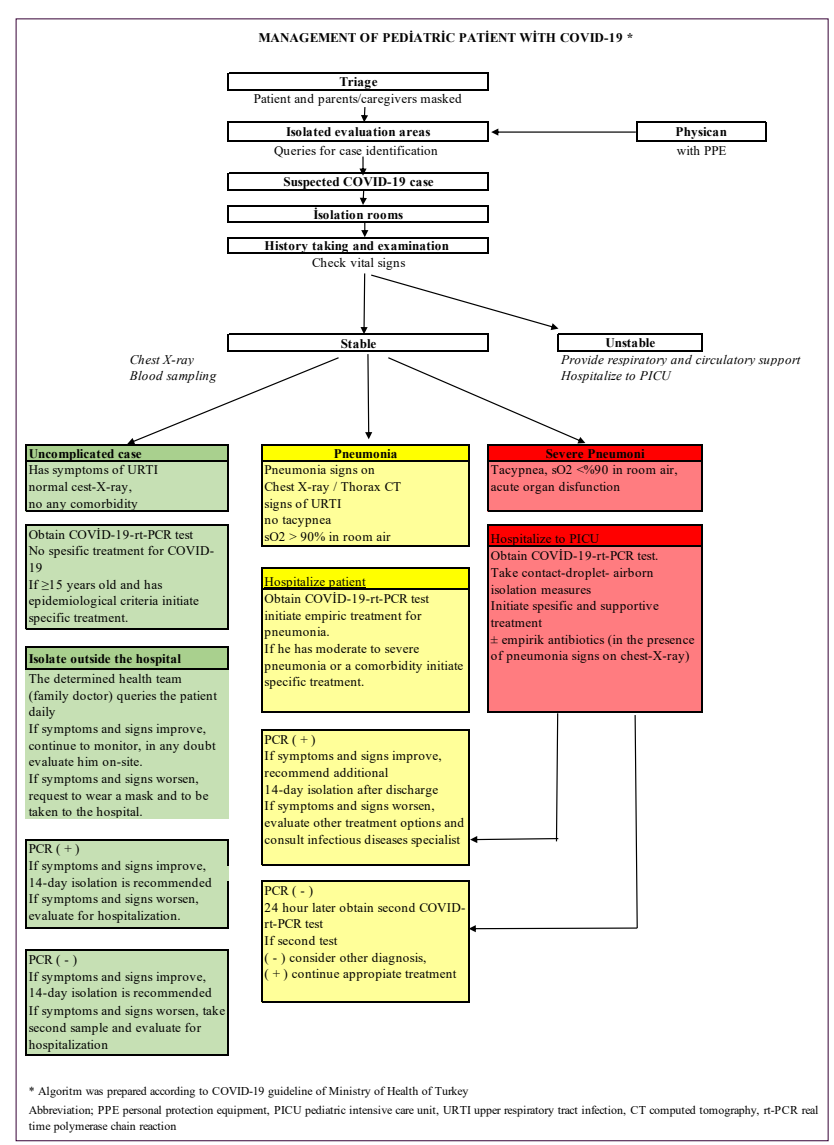

Figure 1. The algorithm used for management of pediatric patient

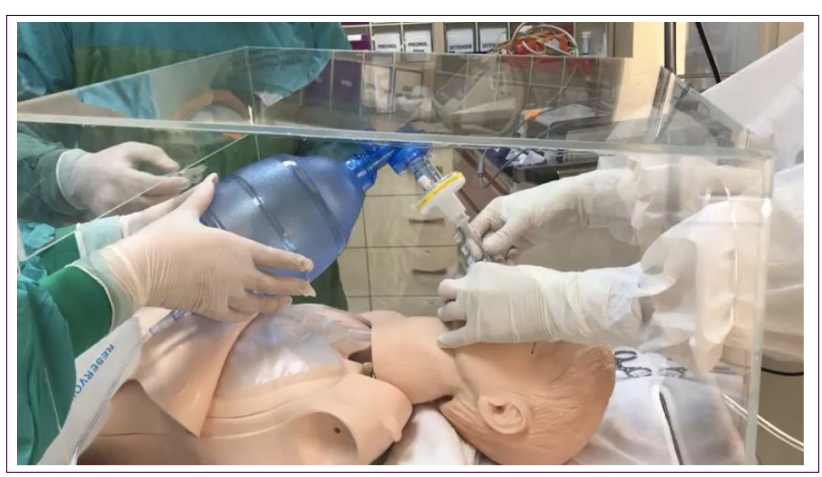

Figure 2. Education of residents about rapid sequential intubation with video-guided laryngoscopy in donated closed-system. 


\section{COVID-19 Case Definition and Nasopharyngeal Swap Testing}

At the beginning of pandemic, while only imported cases were reported in the country, the COVID-19 case definition was made in the presence of travel history to China or the other countries with COVID-19 pandemic in addition to the presence of suspected symptoms. Only in this group COVID-19 real time polymerase chain reaction (rt-PCR) test was performed from nasopharyngeal swap. When community transmission began to be reported, case definition was changed and tests was done according to this new definition (Table 1). Later new version of COVID-19 guideline defined criteria for performing COVID-19 rt-PCR test in children apart from case definition at April 3, 2020 (Table 2). Nasopharyngeal swap sampling of suspected COVID-19 patients was done in isolation rooms after the first evaluation and examination.

\section{Employment of staff}

Since studies reported that COVID-19 has higher morbidity and mortality rate in the elderly and patients with co-morbidities $(4,5)$, in the first 2 months of the outbreak, the period when disease peaked in city, HCWs who were over 65-year-old or who had comorbidities were allowed to have an administrative leave.

As SARS-CoV-2 cause serious illness in adults, workload of physicians of adult were increased in our hospital. To aid them 5 pediatricians and 13 pediatric residents were appointed to the infectious diseases department and adult intensive care unit. Additionally, two or three pediatricians and or residents were infected with SARS-CoV-2 per month, and they were on leave.

So, the number of active-working staff of pediatric

Table 1. Case definition for COVID-19*

\begin{tabular}{|c|c|c|}
\hline $\begin{array}{l}\text { Suspected } \\
\text { case } \\
\text { definition }\end{array}$ & A. & $\begin{array}{l}\text { A history of himself or his / her relative being abroad within } 14 \text { days before the onset of symptomsa AND } \\
\text { At least one of the signs and symptoms of fever or acute respiratory disease (cough and respiratory distress) b AND } \\
\text { Failure to explain the clinical picture with another cause / disease }\end{array}$ \\
\hline & B. & $\begin{array}{l}\text { Close contact with the confirmed COVID-19 case within } 14 \text { days prior to the onset of symptoms, AND } \\
\text { At least one of the signs and symptoms of fever or acute respiratory disease (cough and respiratory distress)b }\end{array}$ \\
\hline & C. & $\begin{array}{l}\text { At least one of the signs and symptoms of fever and severe acute respiratory infection (cough and respiratory distress) AND } \\
\text { Presence of hospitalization requirement (SARI-severe acute respiratory infection)c, AND } \\
\text { Failure to explain the clinical picture with another cause / disease }\end{array}$ \\
\hline & D. & $\begin{array}{l}\text { Sudden onset of fever and cough / shortness of breath and no runny noseb AND, } \\
\text { Failure to explain the clinical picture with another cause / disease }\end{array}$ \\
\hline $\begin{array}{l}\text { Proven case } \\
\text { definition }\end{array}$ & & Among cases that meet the definition of a possible case, cases with SARS-CoV-2 detected by molecular methods. \\
\hline
\end{tabular}

Table 2. COVID-19 rt-PCRa indication in pediatric patients*

\begin{tabular}{|c|c|c|c|}
\hline Criteria & Evaluation & Yes No & $\begin{array}{l}\text { COVID-19 Rt-PCRa } \\
\text { indication }\end{array}$ \\
\hline \multirow[t]{4}{*}{ 1.Epidemiology } & $\begin{array}{l}\text { The presence of household member with history of hospitalization } \\
\text { with a diagnosis of respiratory infection in the last } 14 \text { days. }\end{array}$ & & \\
\hline & The presence household member with COVID - 19 & & \\
\hline & $\begin{array}{l}\text { The presence of household member with fever and cough, or with } \\
\text { complaints respiratory distress with or without fever. }\end{array}$ & & $\begin{array}{l}\text { At least } 1 \text { epidemiological } \\
\text { criteria and } 1 \text { symptom }\end{array}$ \\
\hline & Exposure to someone with COVID-19 & & OR \\
\hline \multirow[t]{5}{*}{ 2.Symptoms } & Fever $\geq 38^{\circ} \mathrm{C}$ or fever history & & 2 symptoms \\
\hline & Findings on chest auscultation & & \\
\hline & Tachypnea & & \\
\hline & New onset cough & & \\
\hline & Oxygen saturation $\leq \% 92$ in room air & & \\
\hline Others & One of following criteria alone & & \\
\hline 4. & Baby <9 months, whose mother COVID-19 (+) & & \\
\hline 5. & The presence of $\geq 2$ household member with COVID-19 (+) & & \\
\hline
\end{tabular}


clinic decreased at the peak of outbreak. Although reduction in the rate of admission of pediatric patients partly balanced this change, to cope with this problem and also to mitigate infectious exposure, all pediatric residents began to work in 24 hours shifts followed by a 48-hour leave. They were divided in the three groups; first group worked in the red zones including pediatric infectious disease ward and isolation rooms of ED and outpatient clinic; second group worked in hematology oncology ward, neonatal and pediatric intensive care units where vulnerable patients were hospitalized; third group worked in general pediatric wards. The working area of these three groups changed every 15 days. Before beginning to work with vulnerable patients HCWs were questioned for symptoms and signs of COVID-19 and if any doubt COVID rt-PCR was performed before shifting their working place.

At beginning of pandemic $\mathrm{MoH}$ thought that during this period decrease in patient admissions would lead to decrease in income of the hospital, thereby in income of healthcare workers (HCWs). So, they increased wages of HCWs in the first 3 months of pandemic. However, no changes in the wage policy have been made since then.

\section{Personal Protecting Equipment (PPE)}

During an infectious disease outbreak providing of HCW safety is essential in order to maintain functioning of health care system. This is possible with taking the right infection control measures. In SARSCoV-1 infection case-control studies demonstrated that consistent droplet and contact precaution was adequate to significantly decrease the risk of infection in HCWs after exposure to patient with infection (6). Another study pointed out that inadequate supply and inconsistent use of PPE are independent risk factors for SARS infection (7). In our hospital, Infection Control Physician planned the supply of PPE and identified acquisition and allocation procedures. Compatible with WHO recommendations, all HCWs took standard and contact precaution and eye protection, additionally any HCW performing an aerosol generating procedure, including nasopharyngeal swap sampling, open suctioning, endotracheal intubation, bronchoscopy on a suspected or confirmed COVID-19 patient, wore respiratory masks such as N95 or FFP2 $(8,9)$. In order to preserve respirators masks for high-risk procedures, other HCWs were recommended to wear surgical/ medical masks. In case of shortage all PPE was supplied for HCWs working in the red zone, for HCWs working in the green zone, one to two surgical masks were supplied each day along with contact precaution and eye protection. When a shortage of gowns appeared, hospital uniform was distributed. Gowns and face masks were also donated by many non-governmental organizations (NGO).

\section{Triage}

Importance of triage in controlling viral respiratory disease outbreak has been highlighted in many studies, and it can provide early recognition of infection and early initiation of infection control measures $(10,11)]$. To control all admissions, two of four entrances of our pediatric clinic were closed, triage was made at the entrance of ED and of outpatient clinic (Figure 3).

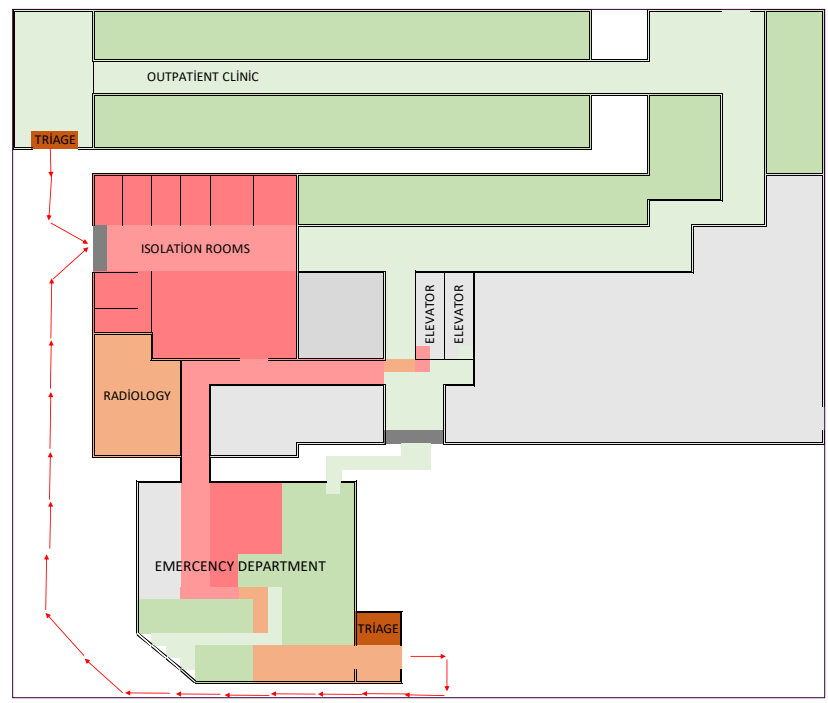

Figure 3. Visitors entered the pediatric clinic through two designated gates in where triage was done.

A donated bungalow was placed in front of pediatric ED to manage patient flow. Here, triage of patients was done according to their need to immediate medical attention and presence of symptoms attributable to COVID-19. They were checked for fever with a noncontact forehead thermometer, symptoms, travel and contact history for COVID-19 were inquired according to questionnaire prepared by the infection control team (Figure 4). All patients and parents/caregivers with COVID-19 symptoms were immediately masked, hand hygiene was provided and redirected with red stamp to the isolation area where they will be evaluated. If these suspected COVID-19 patients needed immediate medical care, they were admitted to isolation rooms of ED; if they had less severe symptoms and could be treated as outpatient, they were admitted to the isolation rooms of outpatient clinic. Patients without COVID-19 symptoms, were redirected with green stamp to green zone of ED or outpatient clinic (Figure 1).

The second entrance was at the outpatient clinic, where a nurse checked fever of patients and parents/ caregivers with non-contact forehead thermometer, and asked symptoms, travel and contact history for COVID-19. Patients with suspicious symptoms or history for COVID-19, were immediately masked and redirected to isolation rooms with a red stamp. 


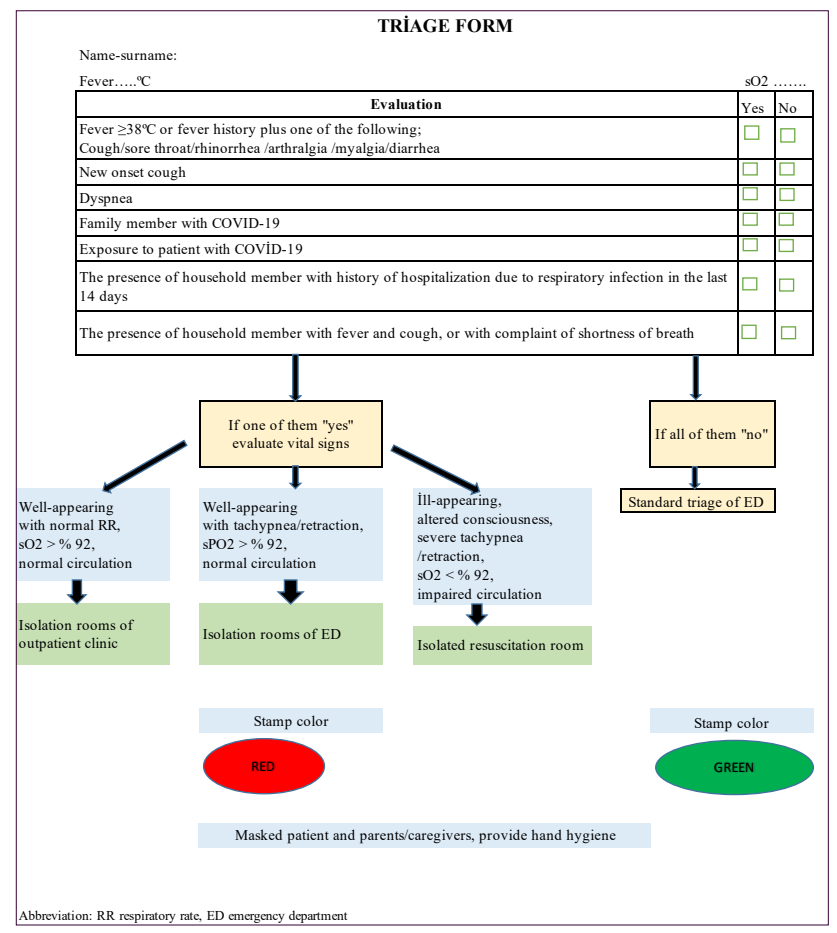

Figure 4. Triage form

\section{Arrangement of Pediatric Wards}

The scientific advisory committee suggested to create separate areas for evaluation and care of suspected or proven COVID-19 cases in all medical care centers throughout the epidemic. Accordingly, we identified "green zone", clean areas for cases without symptoms attributable to COVID-19, and "red zones", the area for suspected or proven COVID-19 cases in the department. Measures were taken to minimize interflow between these two zones. Pediatricians and residents as well as nurses working in these areas were not allowed to enter to the other zones respectively notwithstanding patient relatives.

\section{Emergency Department}

Emergency departments (ED) are the primarily affected areas in outbreak of viral respiratory diseases. To manage increased patient volume and prevent infection spread, re-designing of these wards according to changing needs is required. For preparation to COVID-19 pandemic our ED was divided in to red and green zones. Previously there was only one isolation room for patients with symptoms of infectious diseases. Because of expected high patient volume, another fully-equipped isolation room for resuscitation was constructed and both isolation rooms were completely separated from green zone of ED. These rooms were used to manage suspected or confirmed COVID-19 cases who need immediate medical care (Figure 5).

After the patient was taken to the isolation room, the physician wearing PPE examined him, if he met COVID-19 case definition criteria or had COVID-19 rt-
PCR test indications, nasopharyngeal swab sample was obtained. If needed, intravenous access was established, blood sampling was done and radiography was taken with portable radiographic equipment. Strict infection control measures were taken during these procedures. Since nebulizers can produce aerosol that can evaporate into small infectious droplet and can be pushed over long distances, both in ED and in all other wards of pediatric department their usage was restricted, only metered dose inhalers were allowed. Also, video-guided laryngoscopy, which reduces aerosol formation by reducing the number of failed intubation attempts, was made available in ED (12).

\section{b. Outpatient Clinic}

Outpatient clinic was also re-designed in two parts; red zone (isolation rooms) and a green zone, which were separated from each other completely (Figure 3). In red zone 6 rooms were set-up as isolation rooms, and patient lounge was re-designed according to social distance. One pediatrician, two pediatric residents, two nurses, one support personnel, and one secretary were commissioned in this unit. Patients whom could be treated as outpatient with fever or symptoms of COVID-19 were re-directed from triage of ED and outpatient clinic to this unit. Depending on the patient needs COVID-19rt-PCR test, blood sampling, radiography was obtained and intravenous access was established. All procedures of patient were completed in this area, then s/he was either discharged or hospitalized. For transporting of suspected cases one of the elevators was dedicated. After usage, it was cleaned properly and the next case was taken at least 10 minute later.

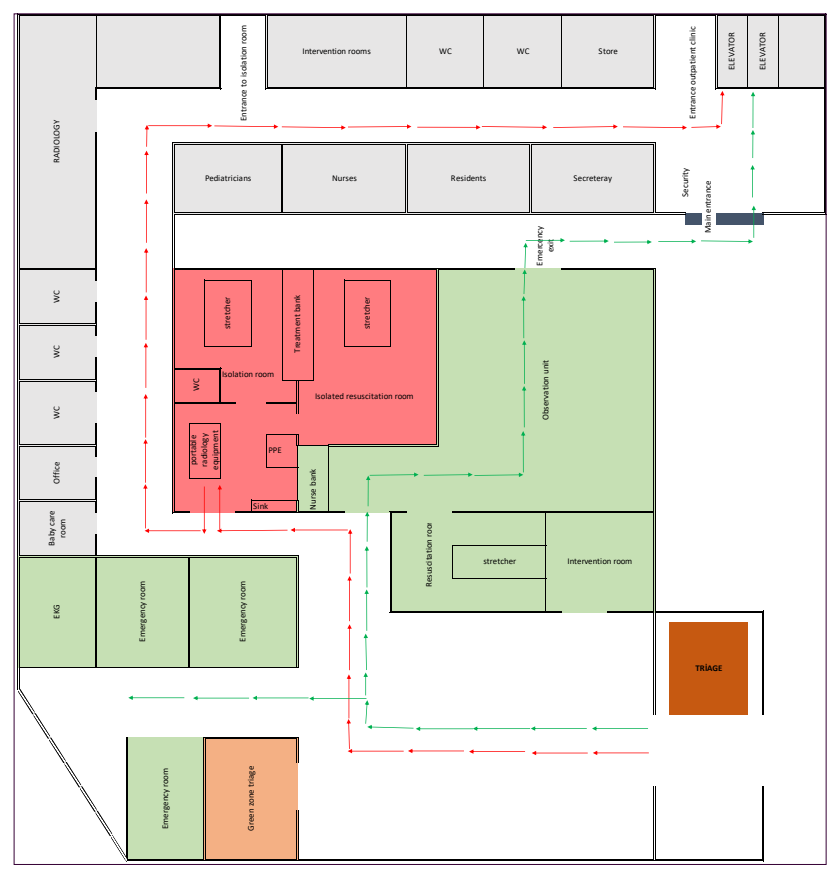

Figure 5. Emergency department (ED) of pediatric clinic after redesigned for COVID-19 pandemic 


\section{c. Pediatric Infectious Diseases Department}

Pediatric Clinic is located an old building and Pediatric Infectious Diseases ward of the hospital had 8 rooms, but none negative pressure rooms. Previously hospitalized patient with infectious diseases other than COVID-19 was transferred to the neighboring general pediatric ward. All rooms' toilets were re-constructed and later, to observe patients and their vital signs frequently, an A4-wide window was opened on their doors. Two rooms were designed for patients who may need assistive respiratory support and managed by pediatric pulmonologist. Strict visitor restriction was applied here. In order to be ready for an increasing number of COVID-19 patients, it was planned to empty the neighboring ward which was used for patients with other infectious diseases. The medical team of pediatric infection diseases ward consist of one pediatric infectious diseases specialist, two welltrained pediatric residents, two nurses and one support personnel.

If two COVID-19 rt-PCR tests taken at least 24 hours apart of suspected COVID-19 cases were negative, the patient was transferred to general pediatric ward. But if a patient had epidemiologic criteria for COVID-19 or if the physician still suspected from COVID-19, even after two negative results, $\mathrm{s} / \mathrm{he}$ was not transferred to general pediatric wards, s/he was discharged directly from this isolated ward after complete recovery. If discharged early, 14-day isolation at home was recommended and related brochures was given to parents/ caregivers. They were advised to call call-center, set up by of HoM, if any suspected COVID-19 symptoms emerged.

\section{d. Pediatric Intensive Care Unit}

Proper ventilatory support and isolation measures had priority in preparedness of Pediatric Intensive Care Unit (PICU) to the COVID-19 pandemic. The effective ventilation procedure with low risk for aerosolization are recommended. Bag-valve-mask (BVM) ventilation before intubation, non-invasive positive pressure ventilation (NIPPV), high-flow nasal cannula, and tracheal intubation itself generate aerosol containing viable respiratory viruses (13). Early intubation was recommended to avoid BVM ventilation, if BMV ventilation is needed a filter should be placed to the equipment (2). Current guidelines suggest the use of high-flow nasal cannula even if it generates aerosol. So, isolation measures are crucial to protect other patients and HCW while intervening with COVID-19 cases. Previously there was only one isolation room in PICU, during preparedness to pandemic another room with two beds was converted into a second isolation room. Physicians wore PPE when entering the rooms of suspected cases, whereas nurses wore PPE constantly, and were cohorted to the COVID-19 cases and worked with the shift system.

\section{e. Neonatal Intensive Care Unit}

In neonatal intensive care unit (NICU) one room was designed for neonates with suspected or confirmed COVID-19. There was no any negative pressure room, we provided a neutral pressure room with droplet, contact, eye-shield precaution and HEPA filter was placed in this room in order to reduce the risk of aerosol spread when the infant needs positive pressure ventilation. Posters showing the infection control measures, were hung on the entrance of the room. To minimize risk of transmission to other patients and $\mathrm{HCWs}$, dedicated HCWs were allocated for these rooms.

\section{f. Radiology Department}

Whenever possible portable radiographic equipment was used, if any patient was required to transport to the radiology department, and if it was not emergent, s/he was accepted as the last patient on that day so that the unit was not crowded. The patient wore appropriate PPE throughout transport. After s/he left unit, all surfaces touched by patient were cleaned, and the next patient was admitter after 10 minutes.

Because of COVID-19 has mild course in children, CT was reserved for patients who had inadequate clinic response after 2-3 days of admission.

\section{g. General Pediatric Wards}

General pediatric wards were used as green zone for hospitalization of children non-suspected for COVID-19. Active surveillance of suspected COVID-19 was done in these wards. For example, if fever and cough developed during hospital stay, which did not improve with antibiotic treatment, a nasopharyngeal swap test was performed, isolation measures were taken and if suspicion for COVID-19 was strong, patient was transferred to infectious diseases ward before the final test result was available.

\section{CONCLUSION}

Strategies and measures taken by a pediatric clinic to confront pandemic were summarized. However, effectiveness of these measures needs to be evaluated. The right measures will vary according to hospital/ department capacity, infrastructure and needs, and also affected by population characteristics. Nowadays ongoing pandemic has serious challenges on health care system and HCWs worldwide. Better management is possible with urgent, well-defined, restrictively conducted effective infection prevention and control measures. All hospitals and healthcare centers should determine their strategies according to their local needs and capacity. 


\section{ETHICAL DECLARATIONS}

Referee Evaluation Process: Externally peer-reviewed.

Conflict of Interest Statement: The authors have no conflicts of interest to declare.

Financial Disclosure: The authors declared that this study has received no financial support.

Author Contributions: All of the authors declare that they have all participated in the design, execution, and analysis of the paper, and that they have approved the final version.

\section{REFERENCES}

1. World Health Organization (2020). Coronavirus disease (COVID-19) Situation Reports-193 [online]. Website: https:// www.who.int/docs/default-source/coronaviruse/situationreports/20200731-covid-19-sitrep-193.pdf?sfvrsn=42a0221d_4.

2. YT Chang, CY Lin, MJ Tsai, et al. Infection Control Measures of a Taiwanese Hospital to Confront the COVID-19 Pandemic. Kaohsiung J Med Sci. 2020; 36: 296-304.

3. Republic of Turkey Ministry of Health. Public health general directorate. COVID-19 (SARS-CoV-2) infection guideline COVID-19 medical advisory committee study. Ankara, Turkey: Republic of Turkey Ministry of Health; 2020.

4. Mcintosh K. Coronavirus Disease 2019 (COVID-19): Clinical features. Hirsch MS (ed), Bloom A (ed). UpToDate: uptodatedJul29, 2020.www.uptodate.com/contents/Coronavirus-Disease-2019(COVID-19):-Clinical features. (Accessed on August 2,2020)

5. Williamson EJ, Walker AJ, Bhaskaran $\mathrm{K}$, et al. Factors associated with COVID-19 related death using OpenSAFELY. Nature. 2020; 584(7821): 430-6.

6. Seto WH, Tsang $D$, Yung RWH, et al. Advisors of Expert SARS group of Hospital Authority. Effectiveness of precautions against droplets and contact in prevention of nosocomial transmission of severe acute respiratory syndrome (SARS). Lancet. 2003; 361(9368):1519-20.

7. Lau JTF, Fung KS, Wong TW, et al. SARS transmission among hospital workers in Hong Kong. Emerging Infect Dis, 2014; 10(2):280-6.

8. Alhazzani W, Møller MH, Arabi YM, et al. Surviving Sepsis campaign: quidelines on the management of critically ill Adults with coronavirus disease 2019 (COVID-19). Crit Care Med. 2020; 48(6): e440-e469.

9. 9.CDC. Coronavirus disease 2019 (COVID-19) [internet]. Centers for Disease Control and Prevention. [cited 2020 August 2] Available from https://www.cdc.gov/coronavirus/2019-ncov/ hcp/index.html; 2020.

10. Jernigan JA, Low DE, Hefland RF. Combining clinical and epidemiologic features for early recognition of SARS. Emerg Infect Dis 2004;10(2):327-33.

11. 11.Whiteside T, Kane E, Aljohani B, Alsamman M, Pourmand A Redesigning emergency department operations amidst a vira pandemic. Am J Emerg Med. 2020; 38(7):1448-53.

12. Lewis SR, Butler AR, Parker J, Cook TM, Smith AF. Video laryngoscopy versus direct laryngoscopy for adult patients requiring tracheal intubation. Cochrane Database Syst Rev. 2016;11(11):CD011136.

13. Tran K, Cimon K, Severn M, Pessoa-Silva CL, Conly J. Aerosol generating procedures and risk of transmission of acute respiratory infections to healthcare workers: A systematic review. PLoS One. 2012;7(4):e35797. 